\title{
HERMENEUTICAL APPROACH FOR QUR'ÂNIC EXEGESIS: An Offer From The West
}

\author{
Sudirman \\ Universitas Islam Negeri (UIN) Maulana Malik Ibrahim Malang Jawa Timur \\ E-mail: sudirmanuinma@gmail.com
}

\begin{abstract}
This article will present the general description of hermeneutical approach, including historical background and phenomenon in understanding the text as well as the Qur'ân. This article will try to portray hermeneutical approach in interpreting Qur'ân which has been discussed by many scholars. It found that hermeneutical approach is an alternative method to understand Qur'ân or even Hadis. It may give a new spirit in developing Qur'ân in terms of its longlasting values. Many modern scholars have undoubtedly struggled to show that Qur'ân will be more 'up-to date' and compatible with the current issues in modern life if we are open to new approach to it. However, not all scholars agree with this method since they believe that Qur'ân is a sacred book which cannot be approached by whatever Western methods, especially hermeneutics. Even, they condemn that the people apply such a method can be categorized as infidel.
\end{abstract}

Keywords: Hermeneutics; Qur'ânic Exegesis; the West.

\begin{abstract}
ABSTRAK
Artikel ini akan menyajikan gambaran umum tentang pendekatan hermeneutis, termasuk latar belakang dan fenomena sejarah dalam memahami teks dan juga al-Qur'an. Artikel ini akan mencoba menggambarkan pendekatan hermeneutis dalam menafsirkan alQur'an yang telah dibahas oleh banyak ilmuwan. Hasil penelitian menunjukkan bahwa pendekatan hermeneutis adalah metode alternatif untuk memahami Al-Qur'an atau bahkan Hadis. Hal ini memberi semangat baru dalam mengembangkan Alquran dalam nilai-nilai yang
\end{abstract}


bertahan lama. Banyak ilmuwan modern berjuang untuk menunjukkan bahwa Alquran akan lebih 'up to date' dan sesuai dengan isu terkini dalam kehidupan modern jika kita terbuka terhadap pendekatan baru terhadapnya. Namun, tidak semua ilmuwan setuju dengan metode ini karena mereka percaya bahwa Alquran adalah kitab suci yang tidak dapat didekati dengan metode Barat manapun, terutama hermeneutika. Bahkan, mereka menyatakan bahwa orang menerapkan metode semacam itu bisa dikategorikan sebagai orang kafir.

Kata kunci: Barat; Hermeneutika; Penafsiran al-Qur’an

\section{A. Introduction}

Qur'ân is commonly believed as a sacred book revealed by God to Muhammad through Jibril for about twenty three years. This revelation transmitted from God orally by Jibril to Muhammad was finally compiled in a book called Mush haf that may make Muslims easily access. However, the transmission of Qur'ân from oral tradition to written text leads to variously logical consequences, particularly in interpreting such a holy book. It is generally known that Qur'ân has a perfect form but is understood, however, by many scholars differently. The question is why each person does understand that sacred book in distinctive way. It is, maybe, due to the different backgrounds and ways of thinking.

Paul Ricoeur (Ricoeur, 1913), clearly mentions several kinds of distanciation process due to his definition that 'text is discourse fixed into writing. These distanciations are related to striking difference between oral and written communication (Thomson (ed.), 1990: 131). In oral communication, the speaker and listener might be in the same place and time that can lead to 'two-way communication. Meanwhile, in written communication the case is different which the writer and the reader probably live in different place and time. Therefore, the communication will be 'one way communication', meaning that the writer and the reader cannot contact each other directly for the writer just keep in touch with the text while the text will be a communication medium for the reader. That communication may be also called as 'impersonal communication' since the media for communication is in the text itself. As a result, if the reader cannot understand the text well, it is hard for him to get further explanation 
moreover if the writer has died of live far away from the reader. This kind of distanciations is called 'distanciation from the text or the author'.

The other distanciation is 'from the context'. In a dialog, every communicant may see each other and clarify what they do not fully understand from the partner, also they can directly refer to the context. On the other hand, when reading the text, even though the writer has sufficiently enclosed the context in the text, it is widely possible to misinterpret the contents of the text since the context is very limited or no longer there.

The distanciation process also happens in Qur'ân which may result in misinterpetation. The first distanciation is the distanciation 'from God'. We cannot ask God what he wants to know deeply the content of Qur'ân. It is unwise, accordingly, if we say that we know what God wants. It may be seen in many cases that some people claim that their idea is the best in understanding Qurân.

Other people are of the opinion that Qur'ân should explain itself (istanthiq Qur'ân). In literary theory, the former is called 'authorcentered interpretation' meaning to give the right of understanding of text to God while the latter is called 'text-centered interpretation' which means interpretation based on the text by, for example, analyzing language, grammar, and structure. The latter theory is directly criticized because text is silent, it depends on the person who interprets the text as Ali says: "Qur'ân khaththun masthûrun bayna daffataini la yanthiqu, innamâ yatakallamu bihî al-nâs" meaning Qur'ân is written text that cannot speak, but the interpreter make it speak (Rahman, 2002).

The literary criticism developing now is 'reader-centered interpretation. The role of reader in seeking and interpreting the text is vitally important. However, this method may lead the reader to go astray and just use their interest in interpreting the text since the presupposition of the reader is always there. Bultmann — as quoted by Yusuf Rahman--maintains that no interpretation without presumption of the reader. The meaning here is that the reader should be open-minded when criticized by the text while reading. But it is different from the ideological assumption which may result in subjectivity of the reader. He just tries to find the justification of his ideology (Ibid). Therefore, it is hard to find 
the right interpretation since every interpreter uses their own context and assumption.

Dealing with that matter, this writing will present the general description of hermeneutical approach including historical background and phenomenon in understanding the text as well as Qur'ân. To know further about that problem, this paper will try to portray hermeneutical approach in interpreting Qur'ân which has been discussed by many scholars such as Hasan Hanafi (al-Turâts wa al-Tajdîd), Farid Esack (Qur'ân, Liberation \& Pluralism), Nasr Hâmid Abû Zaid (Mafhûm alNash) and Muhammad Sahrûr (Al-Kitâb wa Qur'ân: Qirấah Muâshirah). Particularly in this work, I only refer to Abu Zaid's view and example to support this approach in brief.

\section{B. Result and Discussion}

\section{The meaning of 'Hermeunetic'}

'Hermeneutic' is derived from the Greek word 'hermêneuine' and 'hermênia' meaning 'interpreting' and 'interpretation'. That word can be found in various ancient texts such as 'Organon' written by Aristoteles which includes the chapter of 'Peri Hermêneias'. It also can be seen in Oedipus at Colonus, some work of Plato, as well as Xenophon, Plutarch, Euripides, Epicurus, Lucretius, and Longinus. That word is related to Hermes (Hermeios), a messenger of God who has a task to deliver and interpret the unclear message of God to the language of human being (Saenong, 2002: 23). According to Husen Nasr, as quoted by Komaruddin Hidayat, Hermes is believed as Idrîs, whose work was sewing and weaving (Hidayat, 1996: 126). It can be inferred that Idris was always sewing and weaving 'the word' of God.

Gerhard Ebeling, as stated by Saenong, makes the interpretation process of Hermes. There are three steps of basic hermeneutic. Firstly, unveiling the notions which are formerly in the idea by using word (speaking). Secondly, explaining rationally unclear message to be understood. Finally, translating from the foreign language to the language which can be understood by humanbeings. Those three steps can be briefly considered as the activity of interpretation or understanding (Saenong: 24). 
In historical point of view, hermeneutic, as a kind of approaches, has emerged since $17^{\text {th }}$ century but it has not defined philosophically. The term hermeneutic was defined clearly by JC Daahauer in Hermeneutica Sacra Sive Methodus Exponendarums Sacrarum Litterarum in 1654. the scope of that definition was related to the interpretation of Bible. Now, it can be applied in every text including Qur'ân.

\section{The Hermeuneutical Function of Distanciation}

Ricoeur, further, elaborates the notion of the text in the view which testifies the positive and productive function of distanciation at the heart of the historicity of human experience (Ricoeur:131). To begin with, he explains clearly the realization of language as discourse.

Discourse even in oral form, Ricoeur says, displays a primitive type of distanciation which is the condition of possibility of all the characteristics. Discourse is defined as 'an event', so thing happens when someone speaks. The notion of discourse as an event is vitally important when passage is transferred from a linguistics of language or codes to a linguistics of discourse or message (Ibid: 132).

The meaning of event may be understood from various angles:

1. discourse is realized temporally and in the present, whereas the system of language is virtual and outside of time. The eventful character is linked to the person who speaks, the event consists in the fact that someone speaks, someone expresses himself in taking up speech.

2. the sign of language refers only to other signs in the interior of the same system so the language no more has a world that it has a time and a subject, whereas discourse is always about something. The event here is the advent of a world in language by means of discourse. Then, in the work of Scleiermacher and Wilhelm Dilthey, hermeneutics was given philosophically. Scleiermacher, quoted by Ricoeur, states that hermeneutics is the way to bring philology and other interpretation method to the level of 'kunstlehre' that is a technology which is not restricted to a mere collection of unconnected operations. Dilthey, furthermore, developed 
hermeneutics more deeply by utilizing it as methodological foundation of humaniora.

3. Discourse not only has a world but it also has an other, another person, an interlocutor to whom it is addressed. The event is the temporal phenomenon of exchange, the establishment of a dialogue which can be started, continued or interpreted.

Hermeneutics must appeal not only to linguistics but also to the theory of speech acts, as stated by Austin and Searle. The act of the discourse, on their opinion, as encompassed by a hierarchy of subordinate acts distributed on three levels (Ibid: 133).

1. the level of locutionary or promotional act, the act of saying

2. the level of the illocutionary act (or force) what we do in saying

3. the level of the perlocutionary act, what we do by the fact that we speak.

The locutionary act is exteriorized in the sentence qua proposition. For it is as such and such proposition that the sentence can be identified and reidentified as the same. A sentence thus appears as utterance, capable of being conveyed to others with such and such a meaning.

The illocutionary act can also be exteriorised by means of grammatical paradigms and other procedures which mark the illocutionary force of a sentence and thus enable it to be identified and reidentified.

\section{The relation of Speaking and Writing}

Writing seems only to introduce a purely external and material factor: fixation, which shelters the event of discourse from destruction. In fact, fixation is only the external appearance of a problem which is much more important, and which affects all the properties of discourse. Writing renders the text autonomous with respect to the intention of the author. What the text signifies no longer coincides with the author means, hence, textual meaning and psychological meaning have different destinies. The passage from speaking to writing affects discourse in several ways. In particular, the functioning of reference is profoundly altered when it is no longer possible to identify the thing spoken about as part of the common situation of the interlocutors (Ibid: 139-140). 
What happens to reference when discourse becomes a text? Farid Esack questions. Writing and all the structure of the work modify reference to the point of rendering it entirely problematic. In oral discourse, the problem is ultimately resolved by ostensive function of discourse. Reference is determined by the ability to point to the reality common to the interlocutors. If someone cannot point to the thing about which he speaks, at least he can situate it in relation to the unique spatio-temporal network which is shared by interlocutors.

With writing, things already begin to change. There is no longer a situation common to the writer and the reader and the concrete condition of the act no longer exist. This abolition of the ostensive character of reference is no doubt what makes possible the phenomenon called literature, which may abolish all reference to a given reality (Ibid: 141).

\section{Between Text and Context}

Our belief in the eternal relevance of the Qur'ân in not the same as that in a text which is timeless and spaceless. In order to relate Qurânic meaning to the South African crucible, the progressive Islamists were compelled to relate it from some historical moment. The Qur'ân could not have been revelatory had it not been also eventful. There is a theological and historical basis for justifying a contextual approach to the Qur'ân itself and the role of people in elaborating its meaning. This approach has enabled many a progressive Islamists in South Africa to engage the apartheid regime meaningfully in solidarity with religious other (Farid Esack, 1997: 49).

More than fourteen centuries after the revelation of the Qur'ân, in a far southern corner of Africa, believers in the Qur'ân have opened their lives and struggles to the meaning of its message. They have asked the text to enter their context of oppression and struggle for freedom. The hermeneutical issue arises from this encounter between text and context, their implication for the emergence of Qur'ânic hermeneutics as a contemporary discipline and their relation to tradition (Ibid: 50).

The difference between interpreting something on the one hand, and the rules and problems of interpretation on the other is something which has been known from the earlier day of both biblical and Qurânic 
studies. Thus, while the term 'hermeneutics' itself dates back only to the seventeenth century, the operations of textual exegesis and theories of interpretation-religious, literary and legal—date back to antiquity. According to Palmer, two broad streams may be discerned in the search for a definition of hermeneutics. The first stream regards hermeneutic as a general body of methodological principles which underlie interpretation, while the second stream views it as philosophical exploration of the character and necessary condition for all understanding.

Hermeneutics assume that every person comes to a text carrying his or her own questions and expectations and that it would be 'absurd to demand from any interpreter the setting aside of his or her subjectivity and interpret a text without preunderstanding and the questions initiated by it, because without this, the text is mute. In singular form, 'hermeneutic' the conscious acknowledgement of these assumptions is brought to the fore (Ibid: 50-51).

Furthermore, the principle of progressive revelation as is evident from the disciplines of asbâb al-nuzûl and naskh, reflect the notion of the presence of a Divine Entity who manifest His will in terms of the circumstances of His people, who speak to them in terms of their reality and whose word in shaped by those reality.

The disciples of naskh and asbâb al-nuzûl have both come to form significant elements in contemporary attempts to contextualize the message of the Qur'ân, to recapture territory from the ever-expanding unthinkable in Islamic thought. They are being embraced as key elements in braders tapestry of historical relevance, contextuality and justice. Reformist scholars all agree that the task of interpretation today must consider the time, location and an understanding of how tenets and directives respond to the contemporary context. They also share a commitment to the inner unity of the Qur'ân and a rejection of random and selective citation (Ibid: 60).

\section{Hermeneutical Approach in Nasr Abu Zaid's view}

Abu Zaid always begin his view about textuality of Qur'ân by describing the debate between Asy'rites and Mu'tazilites about the sayings of Allah (kalâm allâh) related to the question whether Qur'ân is 'made' or 
not. According to Asy'arites, language is given by God to humanbeings, not the invention of them. The relation between 'signifier' and 'signified', therefore, is decided by God. Qur'ân based on that line of reasoning should be a part of God's divine characteristics which will be remain forever.

On the other hand, Mu'tazilites argue that language is invented by human beings as a social convention about relation between the voice and its meaning. Language does not always refer directly to the actual reality, but to the understood reality symbolized through voice system. Hence, they believe that God has no longer role in such a case resulting in the statement that Qur'ân was created in special context (Ichwan, 2003: 6363). To this point, Abu Zaid strongly agrees with this idea which may put Qur'ân as equal as other texts.

Abu Zaid has a theory about text. Even though he does not explain clearly the meaning of 'text' in his book 'Mafhûm al-nash', Abu Zaid gives a nice description about the distinction between text (nash) and book (mushhaf). Text is 'meaning' while book is 'something' in other word, text is in language whereas book is held in the hand. His theory about text is developed in the framework of text, language, culture, and history. All texts including the sacred text can be analyzed by literary approach. Using discourse analysis and semiotics is really needed.

In his discourse analysis, Abu Zaid differentiates between primary text and secondary text which means Qur'ân and hadis respectively. Hadis as secondary text has a role to explain Qur'ân. It will be the interpretation of the primary text since it is impossible to serve hadis as primary text.

Study about religious text of Islam will be concerned with Qur'ân text and wahy (revelation) because Qurân text is believed as God's revelation to Muhammad through Jibril. Abu Zaid in this case considers the revelation as a part of culture where it emerged. In the pre-Islamic culture, poem and forecasting were transmitted from Jinn through revelation or inspiration. This concept expresses the relation between human beings and Jinn unseen cerature). In Qur'ân, related to the way of Arab thinking, the similar concept is also found, such as the revelation done by malaikat (angels) to the messengers. The text in Qur'ân, thus, tries to symbolize the culture change from poem text (syi îr) and forecasting (kihânah) to the text of Qur'ân, from the poet and fortuneteller to the prophet. 
Realizing his debt to linguist Roman Jacobson's analysis of literary text, Abu Zaid views a text as a form of communication or revelation act. In every communication, Jacobson—as Quoted by Yusuf Rahman--writes (Rahman, 2001: 122):

"The addresser sends a message to the adressee. To be operative the message requires a context referred to ("referrent" in another, somewhat ambigious, nomenclature), seizable by the addressee, and either verbal or capable of being verbalized; a code fully or at least partially, common to the adresser and addresse (or in other words, to the encoder and decoder of the message), and, finally, a contact, a physical channel and pysicological connection between the addresser and the addresee, enabling both them to enter and stay in communication."

Abu Zaid treats Qur'ân, following Jakobson, as a form of an act of communication, wahy, comprised of six elements: a message (risalah), an adresser (mukhâtib), an addressee (mukhâtab), a contact ('alaqah ittishâl), a code (shifrah), and a context ( $\left.w \hat{a} q i^{\prime}\right)$. From these factors, it is possible to describe his notion of text, as Yusuf Rahman does, as "a message sent by an addresser to an addressee in a certain context through a contact using a special code”. And in the case of Qur'ân, wahy is a message sent by God to his messenger through revelation in a certain context using the Arabic language (Ibid: 123). It can simply be seen in the diagram below:

(Context)

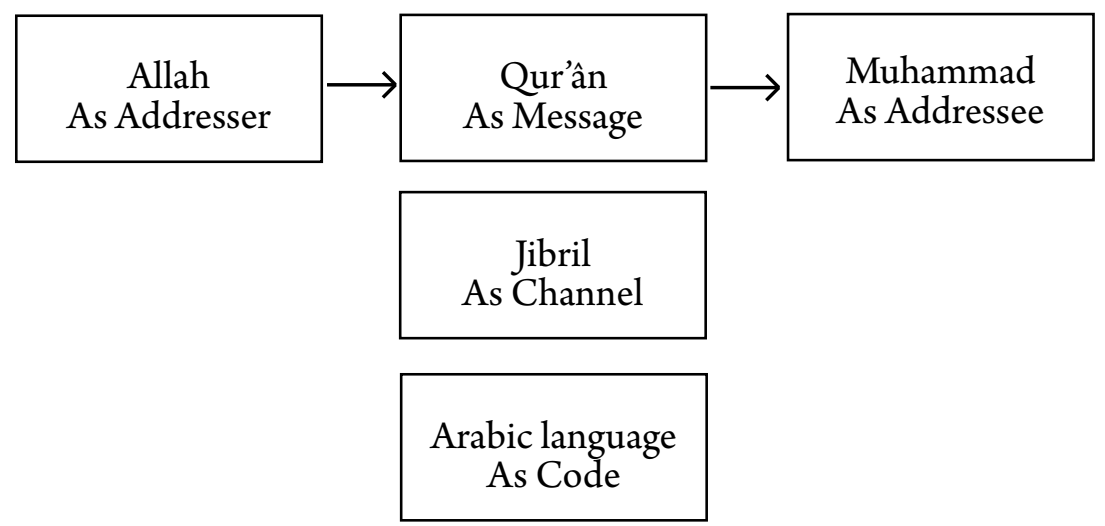

For the real example of Abu Zaid's method is in the problem of interest (ribâ). The discussion about ribâ is nothing new in Egypt. In its second congress, Islamis Research Group declares in its recommendation 
that all kinds of interest, whether for consumptive of productive aspects, are considered illegal (haram). However, some scholars try to give some elaborations, such as Rasyid Ridha stating that the forbidden "ribâ" in Qư'ân is the clear ribâ (ribâ nasi'ah) which is constantly doubled (adh'âfan Mudhâafan). In addition, Said al-Asymawi says that the real meaning of ribâ in Qur'ân is ribâ in pre-Islamic era (ribâ jâhiliyyah) which had a high multiplication resulting in slavery (Ichwan:127).

Abu Zaid is in line with Al-Asymawi arguing that the word ' $r i b \hat{a}$ ' is the ancient language (lughah qâdimah). It is a must to see the context when this verse was revealed. Ribâ cannot be interpreted as interest in modern world since the characteristics of each are widely different. Ribâ in pre-Islamic era was defined as additional amount of money resulting from the barter among people and other transactions which may lead to poverty and slavery. On the other hand, interest in modern context is considered as a profit given to the depositors as a result of economical law. Therefore, Abu Zaid believes that interest is halâl (justified) since it is not ribâ.

\section{Conclusion}

To sum up, hermeneutical approach is an alternative method to understand Qur'ân or even Hadis (Thahir, 2002). It may give a new spirit in developing Qur'ân in terms of its long-lasting values. Many modern scholars have undoubtedly struggled to show that Qur'ân will be more 'up-to date' and compatible with the current issues in modern life if we are open to new approach to it. However, not all scholars agree with this method since they believe that Qur'ân is a sacred book which cannot be approached by whatever Western methods, especially hermeneutics. Even, they condemn that the people apply such a method can be categorized as infidel. Abu Zaid, for instance, has been divorced by the court due to his 'liberal' idea.

Nevertheless, to me, we should appreciate the work of every scholar in interpreting Qur'ân since we do not know what God actually means in His messages. In the beginning of emergence of hermeneutical approach maybe sounds somewhat strange, but finally, we can see that such 'ijtihad' nowadays has successfully triggered a lot of work and discussion. Wa Allâh a'lam bi al-Shawâb. 


\section{BIBLIOGRAPHY}

Arkoun, Muhammed, 1996, Rethinking Islam, Yogyakarta: Pustaka Pelajar

Esack, Farid, 1997, Qur'ân, Liberation \& Pluralism, An Islamic Perspective of Interreligious Solidarity against Oppression, Oxford: Oneword

Faiz, Fakhruddin, 2003, Hermeneutika Qur'âni, antara teks, Konteks, dan Kontekstualisasi, Yogyakarta: Qalam

Hidayat, Komaruddin, 1996, Memahami Bahasa Agama, Sebuah kajian Hermeneutik, Jakarta: Paramadina

Ikhwan, Moch. Nur, 2003, Meretas Kesarjanaan Kritis Qur'ân, Teori Hermeneutika Nasr Abu Zaid, Bandung: Teraju

Jr., E.D., Hirsch, 1978, Validity in Interpretation, London: Yale University Press

Poespoprodjo, 1987, Interpretasi, Beberapa Catatan Pendekatan Filsafatinya, Bandung: Remaja Karya

Howard, Roy J., 2000, Pengantar Teori-teori Pemahaman Kontemporer, Hermeneutika, Wacana Analitik, Psikososial, dan Ontologis, Bandung: Nuansa

Jurnal Teks, Vol. 1, No. 1, Maret 2002, Pasca IAIN Sunan Gunung Djati Bandung.

Jurnal Hermeneia, Vol. 1, No. 1, Januari-Juni 2002, Pasca IAIN Sunan Kalijaga Yogyakarta

Latief, Herman, 2003, Nasr Hamid Abu Zaid, Kritik Teks Keagamaan, Yogyakarta: eLSAQPress

Mustaqim, Ahmad, 2003, Madzahibut Tafsir, Peta Metodologi Penafsiran Qur'ân Metode Klasik Hingga Kontemporer, Yogyakarta: Nun Pustaka

Rahman, Yusuf, 2001, The hermeneutical Theory of Nas Hamid Abu Zaid: An Analytical Study of His Method of Interpreting the Qur'ân, Montreal: McGill University 
, 'Kajian Hermeneutik Pluralitas Tafsir Quran', Jawa Pos, Sunday, 13 January 2002

----------, 'Sakralitas Teks-teks Agama', Kompas, Friday, 18 January 2002

Saenong, Ilham S., 2002, Hermeneutika Pembebasan, Bandung: Teraju

Sumaryono, E., 1999, Hermeneutik, Sebuah Metode Filsafat, Yogyakarta: Kanisius

Syahrur, Muhammad, 1990, Al-Kitab wa Qur'ân Qiraah Mu'ashirah, Damaskus: Al-Ahali

Thomson, John B., 1990, Paul Ricoeur Hermeneutics \& The Human Sciences, Cambridge: Cambridge University Press 
